\title{
UNIVERSITY OF SASKATCHEWAN RADIOCARBON DATES IV
}

\author{
K. J. McCALLUM and J. WITTENBERG \\ University of Saskatchewan, Saskatoon, Saskatchewan, Canada
}

This series reports some of the measurements made since the publication of the previous list. Equipment and methods have been previously described (Saskatchewan II).

\section{ACKNOWLEDGMENTS}

This work was made possible by a grant from the Saskatchewan Research Council, which in addition provided laboratory accommodation.

\section{SAMPLE DESCRIPTIONS}

I. GEOLOGIC SAMPLES

\section{High Prairie series, Alberta}

Mixed organic matter and mud from High Prairie, Alberta $\left(55^{\circ} 28^{\prime} \mathrm{N}\right.$ Lat, $116^{\circ} 30^{\prime} \mathrm{W}$ Long). Eight carbonaceous layers 1 to 3.5 in. thick and separated by clay were found through depth of $93 \mathrm{in}$. in borehole in delta of Heart River, Lesser Slave Lake. Coll. 1960 by R. Deeprose; subm. by C. P. Gravenor, Research Council of Alberta, Edmonton.

S-132. High River, Layer 2, depth 33 in.

S-133. High River, Layer 3, depth 46 in.

S-134. High River, Layer 4, depth 54 in.

S-135. High River, Layer 5, depth 62 in.

S-137. High River, Layer 7, depth 74 in.

$$
\begin{aligned}
& \mathbf{5 5 0} \pm \mathbf{8 0} \\
& \text { A.D. } 1400 \\
& \text { A.D. } 1270 \\
& 680 \pm 100 \\
& 1250 \pm 100 \\
& \text { A.D. } 700 \\
& 1860 \pm 70 \\
& \text { A.D. } 90 \\
& 2050 \pm 100 \\
& 100 \text { B.C. }
\end{aligned}
$$

General Comment: since amount of carbon was small, it was mixed with known amounts of carbon from coal before measurement. Ages of these layers and that of Layer 8, depth 93 in. (S-138, $2500 \pm 170$, Saskatchewan III) give rates of delta sedimentation.

\section{Talara series, Peru}

Shell material from Lobitos Tablazo deposits near Talara, Peru $\left(4^{\circ} 26^{\prime} \mathrm{S}\right.$ Lat, $81^{\circ} 16^{\prime} \mathrm{W}$ Long), from youngest of three Pleistocene beaches, and from modern beach in same area. Coll. and subm. by R. R. H. Lemon, Royal Ontario Mus., Toronto, Canada. 
S-146. Shells of Aequipecten purpuratus

(Lamarck), alt. ca. $67 \mathrm{ft}$

S-147. Donax sp. and Balanus tintinnabulum

(Darwin), alt. ca. $67 \mathrm{ft}$

S-148. Donax sp. and Balanus tintinnabulum (Darwin) from modern beach

$245 \pm 60$ A.D. 1705

General Comment (R.R.H.L.) : S-146 and S-147 collected from loose pebbly coquina; S-148 from wind-blown sand behind modern beach. Geologic and palaentologic evidence suggests Lobitos Tablazo is no more than $15,000 \mathrm{yr}$ old.

\section{S-151. Qu'Appelle Valley, Saskatchewan}

$12,100 \pm 160$ 10,150 в.c.

Travertine from S side slope Qu'Appelle Valley, Saskatchewan $\left(50^{\circ} 46^{\prime}\right.$ $\mathrm{N}$ Lat, $104^{\circ} 39^{\prime} \mathrm{W}$ Long). Deposit extends from a spring $70 \mathrm{ft}$ below top of slope to base of slope. Coll. 1961 by W. H. W. Husband; subm. hy E. A. Christiansen, Saskatchewan Research Council, Saskatoon. Comment (E.A.C.) : Qu'Appelle Valley was apparently cut between 10,150 \pm 200 (S-97, Saskatchewan III) and 12,140 \pm 240 (S.198, Saskatchewan IV). As travertine must postdate valley, contamination with older carbon may have occurred.

\section{S-164. Prince Albert, Saskatchewan}

$$
\begin{array}{r}
1800 \\
\text { A.D. } 150
\end{array}
$$

Charcoal from dune sand, at least 60 in. thick, near Prince Albert, Saskatchewan $\left(53^{\circ} 12^{\prime} 45^{\prime \prime} \mathrm{N}\right.$ Lat, $106^{\circ} 8^{\prime} 30^{\prime \prime} \mathrm{W}$ Long $)$, at depth of 13.5 to 15.5 in. Upper contact is gradational, whereas lower contact of charcoal zone is sharp. Coll. 1960 by H. Kagis and E. A. Christiansen; subm. by E. A. Christiansen. Comment (E.A.C.) : dates a period of dune building.

\section{S-165. Earl Grey, Saskatchewan \\ $10,275 \pm 225$ 8325 в.c.}

Wood from excavation in bottom of dugout at Earl Grey, Saskatchewan $\left(50^{\circ} 46^{\prime} 20^{\prime \prime} \mathrm{N}\right.$ Lat, $104^{\circ} 37^{\prime} 30^{\prime \prime} \mathrm{W}$ Long), from base of gyttja layer $4 \mathrm{ft}$ 10 in. thick, overlain by $13 \mathrm{ft}$ of clay. Below sample was $7 \mathrm{ft}$ clay over till. Coll. 1961 by Paul Guliov; subm. by E. A. Christiansen. Comment (E.A.C.) : date is minimum for retreat of ice from Conde Moraine (Greer and Christiansen, 1963).

\section{S-173. Ceylon, Saskatchewan $\quad 13,000 \pm 200$ 11,050 в.с.}

Marl from crest of knob in area of knob-and-kettle topography near Ceylon, Saskatchewan $\left(49^{\circ} 25^{\prime} \mathrm{N}\right.$ Lat, $104^{\circ} 36^{\prime} \mathrm{W}$ Long), enclosed in fine to medium sand overlain by $3 \mathrm{ft}$ of till. Coll. 1961 by R. Parizek; subm. by E. A. Christiansen. Comment: either dates a glacial readvance or, if the till slid over the marl during melting of underlying ice, is minimum for deglaciation.

\section{S-174. Lancer, Saskatchewan $\quad 10,250 \pm 150$ 8300 в.c.}

Snail and pelecypod shells from $12 \mathrm{ft}$ of medium-grained calcareous sand 
overlain by $4 \mathrm{ft}$ lacustrine silt, near Lancer, Saskatchewan $\left(50^{\circ} 48^{\prime} 52^{\prime \prime} \mathrm{N}\right.$ Lat, $108^{\circ} 56^{\prime} 14^{\prime \prime} \mathrm{W}$ Long). Coll. 1961 by P. P. David; subm. by E. A. Christiansen.

\section{S-175. Boyer Lake, Saskatchewan}

$9250 \pm 150$ 7300 в.C.

Black organic silt from 9-ft bed overlain by $44 \mathrm{ft}$ of organic sand and underlain by $17 \mathrm{ft}$ of silt over sand, from Boyer Lake, Saskatchewan $\left(50^{\circ} 23^{\prime}\right.$ $39^{\prime \prime}$ N Lat, $108^{\circ} 58^{\prime} 26^{\prime \prime}$ W Long). Coll. 1961 by P. P. David; subm. by E. A. Christiansen. Comment (E.A.C.) : dates the silt in the lacustrine complex of Great Sand Hills area.

\section{S-176. Leader, Saskatchewan}

$20,000 \pm 850$ 18,050 в.c.

Organic residue from A-horizon 4 in. thick of buried soil $120 \mathrm{ft}$ below surface from borehole near Leader, Saskatchewan $\left(50^{\circ} 58^{\prime} 54^{\prime \prime} \mathrm{N}\right.$ Lat, $109^{\circ}$ $2 \mathrm{l}^{\prime} 47^{\prime \prime} \mathrm{W}$ Long), overlain by sand, silt, till, silt and lacustrine clay; underlain by B-horizon, till, silt, sand and gravel and till. Comment (E.A.C.) : dates last major glacial advance.

\section{Bainbridge series, Saskatchewan}

Wood from sand and silt $12 \mathrm{ft}$ thick, overlying till in $\mathrm{W}$ bank of new course of Bainbridge Creek, Saskatchewan ( $53^{\circ} 34^{\prime}$ N Lat, $102^{\circ} 07^{\prime} \mathrm{W}$ Long). Coll. 1961 by Henry Kagis; subm. by E. A. Christiansen.

\section{S-178. Bainbridge, Saskatchewan}

Horizontal $\log 6$ in. above till.

\section{S-179. Bainbridge, Saskatchewan}

Vertical $\log$ with roots $3 \mathrm{ft}$ above till.

General Comment (E.A.C.) : samples date two episodes of alluviation.

\section{S-182. Kelliher, Saskatchewan}

$9600 \pm 120$

7650 в.с.

Wood from near top of gyttja overlain by $11 \mathrm{ft}$ of postglacial alluvium and underlain by till near Kelliher, Saskatchewan $\left(51^{\circ} 08^{\prime} \mathrm{N}\right.$ Lat, $103^{\circ} 38^{\prime} \mathrm{W}$ Long). Coll. 1961 by B. A. McCorquodale; subm. by E. A. Christiansen. Comment (E.A.C.) : date is minimum for deglaciation.

\section{S-198. Gunworth, Saskatchewan}

$12,140 \pm 240$ 10,190 в.c.

Charcoal from organic zone in $2 \mathrm{ft}$ thick alluvial deposit beneath $8 \mathrm{ft}$ of till in collapsed hummocky moraine near Gunworth, Saskatchewan $\left(51^{\circ} 18^{\prime}\right.$ $08^{\prime \prime} \mathrm{N}$ Lat, $108^{\circ} 12^{\prime} 30^{\prime \prime} \mathrm{W}$ Long). Coll. 1963 by D. L. Delorme; subm. by E. A. Christiansen. Comment (E.A.C.) : either dates readvance or, if the till slid over organic zone during melting of underlying ice, is minimum for deglaciation.
S-227. Green, Saskatchewan$$
10,800 \pm 160
$$$$
8850 \text { в.C. }
$$

Charcoal at depth 30 to $31 \mathrm{in}$. in contorted calcareous lake silt at least $8 \mathrm{ft}$ 
thick, near Green, Saskatchewan $\left(51^{\circ} 36^{\prime} \mathrm{N}\right.$ Lat, $109^{\circ} 57^{\prime} \mathrm{W}$ Long). Coll. 1963 by D. L. Delorme; subm. by E. A. Christiansen.

\section{Lake St. Clair Delta series, Ontario}

Wood and gyttja from excavation in Lake St. Clair Delta area, Ontario, Canada. Typical stratigraphy of area is an upper zone of 1 to $2 \mathrm{ft}$ organic soil or muck underlain by sand, silty sand with wood, peat grading upward into gyttja; then lacustrine clay. S-161 was taken from the silty sand layer at Walpole Island, Ontario $\left(42^{\circ} 33^{\prime} \mathrm{N}\right.$ Lat, $82^{\circ} 32^{\prime} \mathrm{W}$ Long), and S-162 from the gyttja layer at Squirrel Island $\left(42^{\circ} 34^{\prime} \mathrm{N}\right.$ Lat, $82^{\circ} 35^{\prime} \mathrm{W}$ Long $), 3 \mathrm{mi}$ W of S-161. Coll. 1961 by W. R. Wightman; subm. by A. Dreimanis, Univ. of Western Ontario, London, Canada.

\section{S-161. Lake St. Clair Delta, Walpole Island, wood $6100 \pm 80$ \\ S-162. Lake St. Clair Delta, Squirrel Island, gyttja $\mathbf{7 3 0 0} \pm \mathbf{8 0}$}

General Comment (A.D.): wood was probably washed out from peat and gyttja layer and redeposited at beginning of the Nipissing time, $4600 \pm 210$ (S-24, Saskatchewan II). Gyttja had peat at its base. Change from peat to a gyttja implies either submergence, for which no evidence is known, or change from dry Boreal to moister Atlantic climate. Deevey and Flint (1957) placed this transition at ca. 8500 B.P. Pollen analysis by R. J. Mott (Geol. Survey of Canada) shows that oak $(48 \%)$ and pine $(24 \%)$ were dominant during deposition of the gyttja.

\section{S-172. Tupperville, Ontario $\quad 12,000 \pm 200$ \\ 10,050 в.c.}

Plant remains from Perry Farm mastodon site $0.4 \mathrm{mi}$ NE of Tupperville, Ontario (42 $35^{\prime} 30^{\prime \prime} \mathrm{N}$ Lat, $81^{\circ} 16^{\prime} \mathrm{W}$ Long), from top $6 \mathrm{in}$. of lacustrine clayey calcareous silt covered by a sand bar. Coll. 1961 and subm. by A. Dreimanis. Comment (A.D.) : pollen of spruce have been found among the plant remains, suggesting a cool climate. Silt layer was deposited in Sydenham River delta in the Early Lake St. Clair and was later covered by beach sand of the same lake. Date is minimum for inception of lake.

\section{Lillestrom series, Saskatchewan}

Gyttja from near Lillestrom, Saskatchewan $\left(50^{\circ} 20^{\prime} \mathrm{N}\right.$ Lat, $105^{\circ} 54^{\prime} \mathrm{W}$ Long). Coll. 1962 and subm. by J. C. Ritchie, Dept. of Botany, Univ. of Manitoba, Canada.

S-188. Gyttja, depth $2.85 \mathrm{~m}$

S-189. Gyttja, depth $3.90 \mathrm{~m}$

S-190. Gyttja, depth $4.95 \mathrm{~m}$

$$
\begin{gathered}
10,270 \pm 150 \\
8320 \text { в.с. } \\
10,630 \pm 150 \\
8680 \text { в.с. } \\
11,650 \pm 150 \\
9700 \text { в.с. }
\end{gathered}
$$

General Comment (J.C.R.) : macro- and micro-plant remains in the gyttja in- 
dicate spruce associated with poplar. Pollen indicates cool wet period followed by warmer interval and return to cool wet. As site lies $\mathrm{S}$ of Moose Jaw Moraine, sample possibly dates time between retreat from that moraine and readvance to Condie Moraine (Christiansen, 1961).

\section{S-191. Banff National Park, Alberta}

$6020 \pm 90$ 4070 B.C.

Forest litter and charcoal from buried soil 1 in. thick, on NE side on Banff Natl. Park highway, Alberta $\left(51^{\circ} 59^{\prime} \mathrm{N}\right.$ Lat, $116^{\circ} 47^{\prime} \mathrm{W}$ Long). Buried soil underlies gravelly ablation till and overlies ablation till and silt. Coll. 1961 and subm. by A. Dreimanis. Comment (A.D.) : the soil accumulated during a PostWisconsin deglaciation, probably including the Hypsithermal, and was covered by glacial readvance (perhaps of existing glaciers now 10 to $20 \mathrm{mi}$ distant) during early part of "Little Ice Age."

\section{S-208. Wellsburg, New York}

$410 \pm 150$

\section{A.D. 1540}

Wood in alluvium, from overflow channel of Chemung River, New York ( $41^{\circ} 58^{\prime} \mathrm{N}$ Lat, $76^{\circ} 45^{\prime} \mathrm{W}$ Long), at depth $5.5 \mathrm{ft}$. Coll. 1963 and subm. by J. G. Nelson, Dept. Geography, Univ. of Alberta, Calgary. Comment: small sample was mixed with old carbon before measurement. Age measures rate of deposition of overbank alluvium, since sample is now $5.5 \mathrm{ft}$ below surface.

\section{S-184. Coffin Island (Magdalen Islands), Quebec $\quad 2175 \pm 70$ \\ 225 B.c.}

Crassostrea virginica from beach on outer eastern shore of Coffin Island, Quebec $\left(47^{\circ} 30^{\prime} \mathrm{N}\right.$ Lat, $61^{\circ} 30^{\prime} \mathrm{W}$ Long), after storms. Coll. 1960 by S. E. Vass; subm. by J. C. Medcof, Fisheries Research Board, St. Andrews, New Brunswick. Comment (J.C.M.) : no oysters in this area now; shells probably washed up from an extinct bed; date probably corresponds with a period when oysters flourished and when water was warmer and perhaps shallower.

\section{S-185. Murray Harbour, Prince Edward Island \\ $6850 \pm 100$}

Crassostrea virginica taken in a hydraulic dredge from depth of 20 fathoms in Northumberland Strait, 4 to $6 \mathrm{mi}$ off mouth of Murray Harbour, Prince Edward Island $\left(46^{\circ} 00^{\prime} \mathrm{N}\right.$ Lat, $62^{\circ} 37^{\prime} \mathrm{W}$ Long). Coll. 1958 and subm. by J. C. Medcof. Comment (J.C.M.) : same as for S-184.

\section{S-186. Georges Bank, Nova Scotia}

$$
\begin{aligned}
& 10,600 \pm 130 \\
& 8650 \text { в.C. }
\end{aligned}
$$

Crassostrea virginica taken in a scallop drag from depth of 28 fathoms

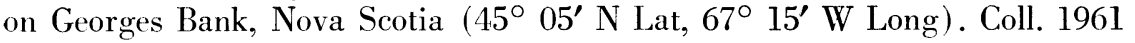
and subm. by J. C. Medcof. Comment (J.C.M.) : same as for S-184.

\section{ARCHAEOLOGIC SAMPLES}

\section{Reid Site series, Nova Scotia}

Charcoal and shell material from Reid Site, Indian Point, St. Margaret's Bay, Nova Scotia (44. $38^{\prime} 40^{\prime \prime} \mathrm{N}$ Lat, $63^{\circ} 54^{\prime} 55^{\prime \prime} \mathrm{W}$ Long). Charcoal sample was from lowest of three levels, the only one with culturally datable artifacts. 
These consisted of small corner-notched projectile points of semi-crystalline siliceous material. Mercenaria shells were from all levels of an associated shell heap. Coll. 1960 by J. S. Erskine; subm. by A. H. Clarke, Nat. Mus. of Canada, Ottawa.

\section{S-153. Charcoal from third level}

\section{S-187. Mercenaria shells}

$600 \pm 45$
A.D. 1350

A.D. 1450

$500 \pm 60$

General Comment (J.S.E.) : Littorina littorea shells from this site have been dated at $700 \pm 225$ (Clarke and Erskine, 1961). It was considered on archaeological grounds that this side would have been occupied for not less than a century between A.D. 1200-1500.

\section{S-158. Bear River, Nova Scotia}

$2125 \pm 65$ 175 B.c.

Charcoal from hearth at wigwam shelf levelled out of glacial terrace, Bear River, Nova Scotia $\left(44^{\circ} 37^{\prime} 30^{\prime \prime} \mathrm{N}\right.$ Lat, $65^{\circ} 42^{\prime} \mathrm{W}$ Long). Upper 10 in. contained projectile points of siliceous slate, usually corner-notched. Below $10 \mathrm{in}$. the points were stemmed or side-notched and usually of quartzite, a type associated in Maine with a Late Boreal Archaic horizon but here with Woodland pottery. Charcoal was at a depth of $15 \mathrm{in}$. in upper third of this "lower Bear River" level. Coll. 1959 by J. S. Erskine; subm. by A. H. Clarke. Comment (J.S.E.) : since much Woodland pottery is found below 15 in. at Bear River this culture in Nova Scotia must have begun earlier than 175 в.c.

\section{Whynacht Cove series}

Charcoal and oyster shells from Whynacht Cove, Mahone Bay, Nova Scotia $\left(44^{\circ} 27^{\prime} 34^{\prime \prime} \mathrm{N}\right.$ Lat, 64 $14^{\circ} 33^{\prime \prime} \mathrm{W}$ Long). Charcoal came from the uppermost and shells from the lowest of three levels in an Indian shell heap. Coll. 1960 by J. S. Erskine; subm. by A. H. Clarke.

\section{S-154. Whynacht Cove, First level, Charcoal \\ A.D. 1050 \\ S-183. Whynacht Cove, Third level, Shells \\ $1290 \pm 75$ A.D. 660}

General Comment (J.S.E.) : first level contained Indian Gardens points, with antler-tines of white-tailed deer near the bottom and fragments of caribou antler in the upper $8 \mathrm{in}$. This represents earliest definite find of caribou in Nova Scotia. Oysters are now locally extinct, and no oyster shells were found in upper levels of this site.

\section{TROPOSPHERIC RADIOCARBON}

The $\mathrm{C}^{14}$ content of wheat seeds grown since those reported in Saskatchewan III have been determined. These were grown at (1) Research Branch, Dominion Experimental Farm, Scott, Saskatchewan $\left(52^{\circ} 23^{\prime} \mathrm{N}\right.$ Lat, $108^{\circ} 50^{\prime}$ W Long), and (2) Crop Science Department, Univ. of Saskatchewan, Saskatoon $\left(52^{\circ} 27^{\prime} \mathrm{N}\right.$ Lat, $106^{\circ} 38^{\prime} \mathrm{W}$ Long $)$. Changes in $\mathrm{C}^{14}$ content are expressed 
in terms of the quantity $\Delta$ (Broecker and Olson, 1961) assuming the value of $\delta \mathrm{C}^{13}$ to be $-25 \%$.

\begin{tabular}{|c|c|c|c|}
\hline Sample No. & Year & Location & $\Delta$ \\
\hline S-319 & 1962 & Saskatoon & $408 \pm 9$ \\
\hline S-320 & 1962 & Scott & $452 \pm 10$ \\
\hline S-321 & 1963 & Saskatoon & $955 \pm 17$ \\
\hline S-322 & 1963 & Scott & $913 \pm 10$ \\
\hline
\end{tabular}

Comment: the pronounced increase in tropospheric $\mathrm{C}^{14}$ following the decrease in 1959-61 is evident at these latitudes.

Date lists:

\section{RefERENCES}

Saskatchewan II McCallum and Dyck, 1960

Saskatchewan III McCallum and Wittenberg, 1962

Broecker, W. S., and Olson, E. A., 1961, Lamont radiocarbon measurements VIII: Radiocarbon, $\mathrm{v}, 3, \mathrm{P}, 176-204$

Christiansen, E. A., 1961, Geology and ground-water resources of the Regina area, Saskatchewan: Saskatchewan Research Council, Geol. Div., Rept. 2, p. 16 and 48.

Clarke, A. H., and Erskine, J. S., 1961, Pre-Columbian Littorina littorea in Nova Scotia: Science, v. 134, p. 393-394.

Deevey, E. S., and Flint, R. F., 1957, Postglacial hypsithermal interval: Science, v. 125,

p. 182-184.
Greer, L. E., and Christiansen, E. A., 1963, Geology and ground-water resources of the Wynyard area, Saskatchewan: Saskatchewan Research Council, Geol. Div., Rept. 3,

p. 35.
McCallum, K. J., and Dyck, W., 1960, University of Saskatchewan radiocarbon dates II: Am. Jour. Sci. Radioc. Supp., v. 2 , p. 73-81.

McCallum, K. J., and Wittenberg, J., 1962, University of Saskatchewan radiocarbon dates III: Radiocarbon, v. 4, p. 71-80. 